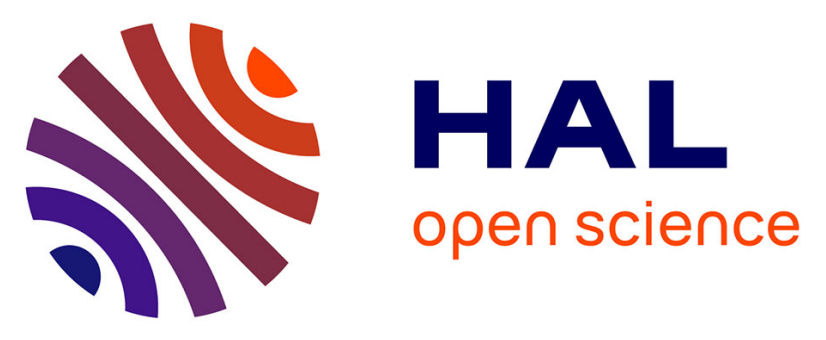

\title{
The Montérégie Connection: Understanding How Ecosystems Can Provide Resilience to the Risk of Ecosystem Service Change
}

\author{
Elena M. Bennett, Cecile H. Albert, Aaron Ball, Jeffrey Cardille, Karine \\ Dancose, Sylvestre Delmotte, Andrew Gonzalez, Hsin Hui-Huang, Martin J. \\ Lechowicz, Katie Liss, et al.
}

\section{To cite this version:}

Elena M. Bennett, Cecile H. Albert, Aaron Ball, Jeffrey Cardille, Karine Dancose, et al.. The Montérégie Connection: Understanding How Ecosystems Can Provide Resilience to the Risk of Ecosystem Service Change. Atlas of Ecosystem Services: Drivers, Risks, and Societal Responses, Springer International Publishing, 2019, 978-3-319-96228-3. hal-02010820

\section{HAL Id: hal-02010820 \\ https://hal-amu.archives-ouvertes.fr/hal-02010820}

Submitted on 7 Feb 2019

HAL is a multi-disciplinary open access archive for the deposit and dissemination of scientific research documents, whether they are published or not. The documents may come from teaching and research institutions in France or abroad, or from public or private research centers.
L'archive ouverte pluridisciplinaire HAL, est destinée au dépôt et à la diffusion de documents scientifiques de niveau recherche, publiés ou non, émanant des établissements d'enseignement et de recherche français ou étrangers, des laboratoires publics ou privés. 


\title{
The Montérégie Connection: Understanding How Ecosystems Can Provide Resilience to the Risk of Ecosystem Service Change
}

\author{
Elena M. Bennett, Cecile Albert, Aaron Ball, \\ Jeffrey Cardille, Karine Dancose, Sylvestre Delmotte, \\ Andrew Gonzalez, Hsin Hui-Huang, Martin Lechowicz, \\ Katie Liss, Rebekah Kipp, Dorothy Maguire, \\ Shauna Mahajan, Matthew Mitchell, Kyle Teixeira-Martins, \\ Ciara Raudsepp-Hearne, Delphine Renard, \\ Jeanine Rhemtulla, Lucie Taliana, Marta Terrado, \\ and Carly Ziter.
}

\section{Introduction}

Communities manage their landscape and the biodiversity within it to provide various ecosystem services (ES) such as high-quality water, food, and recreation. Provision of these services is a sensitive indicator of ecosystem health, and is also critical to human well-being. To successfully manage both ES and biodiversity, communities need reliable, objective information and effective tools to evaluate how human activities and social-ecological dynamics will alter the landscape structure that affects the maintenance of biodiversity and ES provision.

The Montérégie Connection project aimed to help the community of this agricultural region just southeast of Montreal to improve management of multiple ecosystem services by developing and empirically testing a modeling framework that quantitatively linked landscape connectivity, biodiversity, and ecosystem services in this region. We will use this framework to build scenarios and other practical decision-support tools with communities to help them grapple with the challenges of environmental management in the face of local, regional, and global change. We focused especially on how forest connectivity and forest corridors might help the local landscape maintain biodiversity and provide the desired ES in the face of these changes.

The Montérégie Connection project study area is located to the southeast of Montreal, Canada (Fig. 45.1). It is in the Mixedwood Plains ecozone and St. Lawrence Lowlands ecoregion of southern Québec, Canada. This region has warm summers and cold, snowy winters with a mean annual temperature of $\sim 5^{\circ} \mathrm{C}$ and average seasonal temperatures that range from $16.5^{\circ} \mathrm{C}$ in the summer to $-7^{\circ} \mathrm{C}$ in the winter. Mean annual precipitation varies between 800 and $1000 \mathrm{~mm}$. The terrain is
Which ecosystemservicesareaddressed? Provisioning: agricultural production (crops, pork), provision of clean water, maple syrup production, milk production

Regulating: flood control, regulation of nutrient cycling, carbon storage for climate regulation, soil organic matter, pollination

Cultural: hunting opportunities, nature appreciation, tourism, forest recreation

What is the research question addressed? The overarching questions that drove the research project were as follows:

(1) How can the Vallée-du-Richelieu Municipalité Régionale de Comté (VR-MRC) manage the local landscape to maintain biodiversity and provide desired ecosystem services (ES) in the face of regional and global change?

(2) How would development of a network of forest corridors linking natural areas in the VR-MRC affect current and future biodiversity and the provision of ES?

(3) How does the location and size of these corridors alter the provision of biodiversity and ES?

Which method has been applied? We used a variety of methods, including the use of existing government records to map ecosystem services at larger (municipal and county) scales, a broad set of fieldwork methods to measure ecosystem services directly at smaller scales, and a variety of modelling methods to link these field methods with government data to consider possible future provision of services 


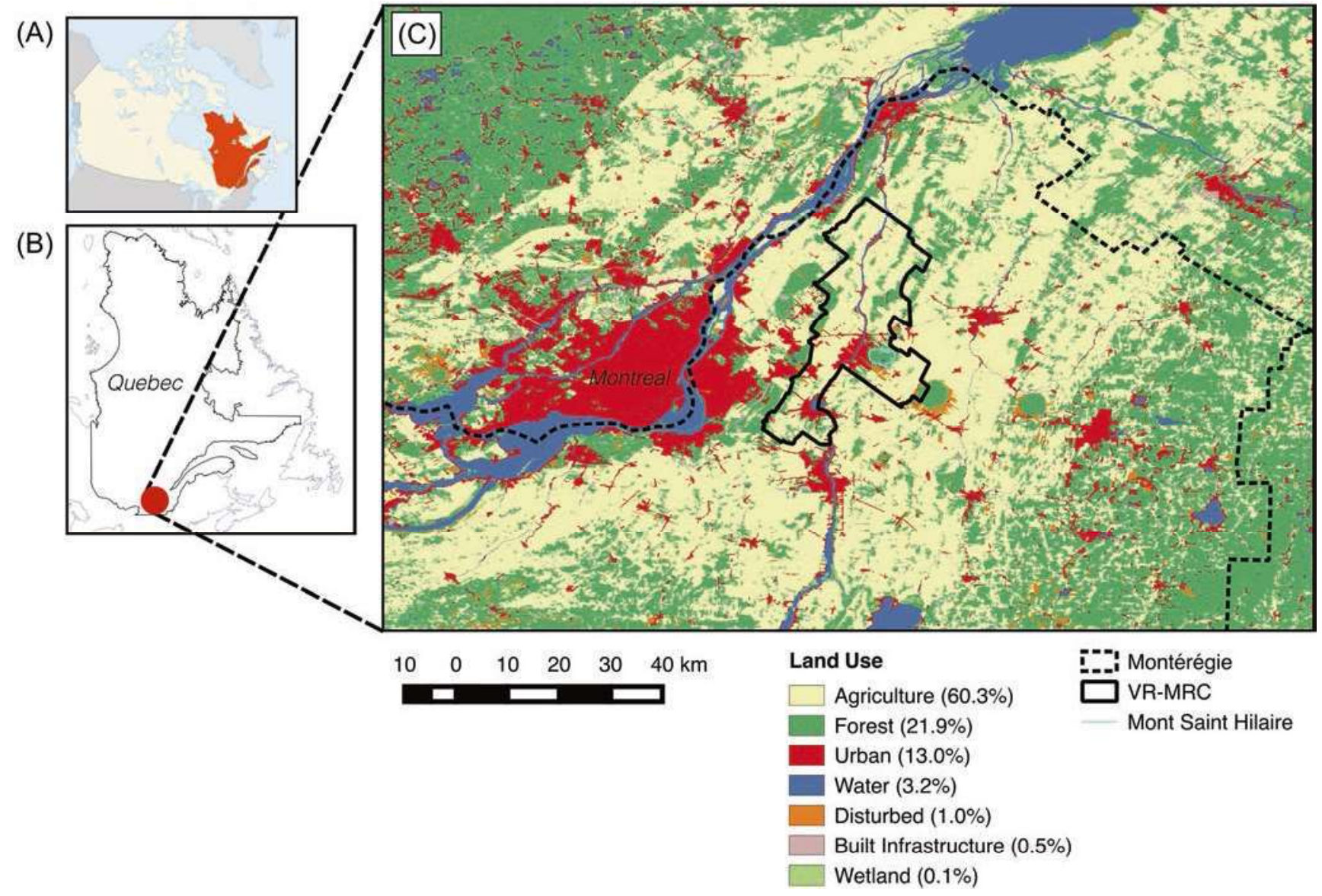

Fig. 45.1 Land use/land cover in the Montérégie and surrounding area. (a) The location of Quebec within Canada. (b) The location of the Montérégie in southern Quebec. (c) Southeastern Quebec, including Montreal and the Montérégie. The Montérégie Connection project fieldwork, models, and scenarios have focused on the Vallée du Richelieu Municipalité Regionale CComté (VR-MRC, outlined in solid black). Proportions of land use within the VR-MRCC are shown in the legend. (Reproduced from Mitchell et al. [4]) quite flat and, below $150 \mathrm{~m}$, dominated by poorly drained clay deposits upon which gleysolic soils have developed [1]. In this generally flat milieu, several Montérégian hills, isolated plutonic intrusions that range from $\sim 200-400 \mathrm{~m}$ in height, are also present [2]. These hills are forested, often reserved and highly valued for recreation, and are important reservoirs of plant and animal biodiversity in the region.

The administrative unit of the Montérégie is $\sim 11,000 \mathrm{~km}^{2}$ and has a population of approximately 1.4 million people ( $18 \%$ of Québec's population). It contains ecosystems with the highest levels of biodiversity in the province [3] and consists of a mosaic of urban, periurban, rural, and agricultural areas (Fig. 45.1) [4]. Rural communities and agriculture have historically dominated this landscape, but the type of agriculture has changed through time. A shift from dairy farming to intensively managed corn and soybean fields has occurred in recent decades, leading to more annual crops, fewer farms, and increases in pesticide and fertilizer use [1, 5]. Apple orchards are concentrated on the well-drained gravel slopes of the Montérégian hills. Numerous, mostly small, residual
What is the main result? Ecosystem service provision is the outcome of a complex set of interacting social and ecological factors that are difficult to understand and manage. Understanding basic principles and working to anticipate the unexpected can help societies move forward protecting the long-term security of the many ecosystem services they desire

What is concluded, recommended? Working with local stakeholders in active listening can improve research and its ultimate uptake in policy- and decision-making

deciduous and mixedwood forest fragments are present and provide important ES, including maple syrup production, but very few municipalities have more than $30 \%$ forest cover. Because of its proximity to Montreal, the region is currently undergoing significant residential development and expansion of periurban areas [6], which is causing significant loss of bio- 
diversity $[1,5]$ and is putting pressure on local land managers to achieve provision of multiple ES across the landscape.

The intensity of human use in this region-and demand for ES-requires effective management to maintain the provision of multiple ES into the future. Because land use and management are key drivers in this system, at issue is the need to move from landscape management that focuses on one service at a time (typically, for this region, either food production, recreation, or biodiversity) to a management that focuses on maintaining multi-functional landscapes. This type of decision-making can be improved through development of theory, data, and models that link landscapes, their biodiversity and functions, and ecosystem services at the scales at which decisions are made [7]. Our overarching goal as a project was to work with the community to facilitate improved decision-making by discussing theory of, collecting data about, and developing models on the linkages between landscapes, biodiversity, and ecosystem services.

\section{Current State of the Montérégie}

Many ecosystem services are provided across this region, including food, water, opportunities for recreation and tourism, carbon sequestration, pollination, pest regulation, water quality regulation, hunting, maple syrup production, and aesthetic and spiritual connections to nature [8-11]. These services are provided across the landscape in a variety of unique patterns (Fig. 45.2) which, in turn, are driven by a combination of factors, including where it is possible to produce services, biophysically and ecologically; human desire for services, and interactions between services [8].

The strongly linked spatial distributions of multiple ecosystem services translates into an emergent pattern of municipalities with similar sets of ecosystem services, which we call bundles. Different bundles exist on the landscape in relation to the social-ecological system (Fig. 45.3) [8]; for example, municipalities on the landscape that are known to be destinations for cottagers were grouped together in what we call the Country Homes bundle type, which has high provision of forest recreation, carbon sequestration, highquality water, phosphorus retention, and soil organic matter. Other municipalities known for agriculture might be grouped in either the Corn-Soy Ag bundle (high soil P retention and crop production, along with good water quality) or the Feedlot Ag bundle (low water quality and low provision of most services besides pork and crops).

The locations of provision of these services, and the services themselves, have shifted over time [12]. At the earliest dates for which we could obtain data on multiple ecosystem services, most municipalities provided a broad mix of services (e.g., providing crops, animal products, and flood control). Through time, most municipalities began to specialize in provision of one or two services (e.g., on recre-

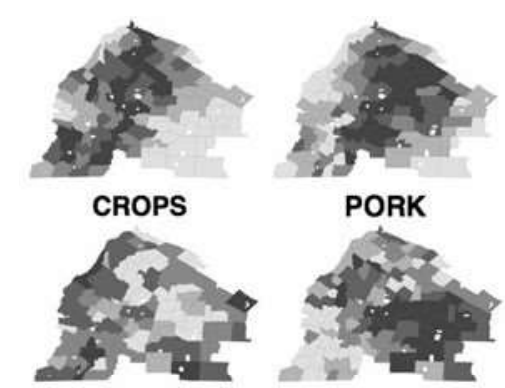

DRINKING WATER MAPLE SYRUP
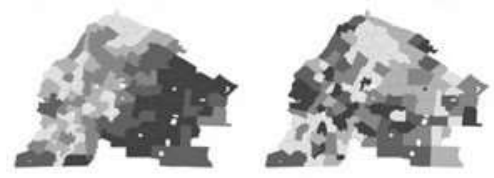

DEER HUNTING

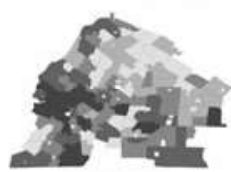

TOURISM

NATURE

APPRECIATION

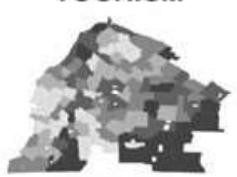

SUMMER

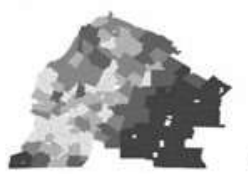

COTTAGES

FOREST

RECREATION

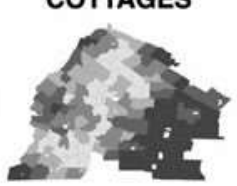

CARBON

ES VALUES

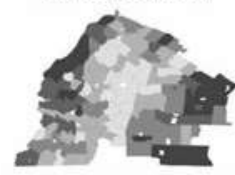

SOIL PHOSPHORUS RETENTION
SEQUESTRATION (QUINTILES)

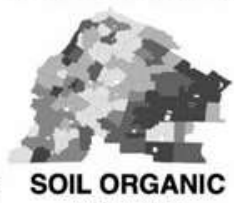

MATTER

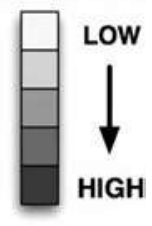

Fig. 45.2 Distributions of 12 ecosystem services, shown in quintiles. The gradient of light-to-dark grey corresponds with low-to-high values of ecosystem service provision. The area of this map corresponds to the dashed-line outline of the administrative boundary of the Montérégie in Fig. 45.1, but extends slightly further to the east to incorporate two entire watersheds. (Reproduced from Raudsepp-Hearne et al. [8])

ation alone). Over the entire region, provision of most services remained, and even increased, but this increase was spatially specialized by municipality (Fig. 45.4) [12].

Correlation analysis also revealed that the interactions among some services changed [12]. For example, some relationships, such as that between carbon storage and hunting, increased in strength through time, and others (carbon storage and other recreational activities) became weaker. Other relationships changed entirely, such as the relationship between hunting and livestock production-negative at the start of the study, and positive by the end of it. While we do not know for sure the causes of these changes, hypotheses can easily be developed. For example, it may be that hunting and livestock production were negatively correlated in the early part of the study because animals were kept in pastures and competed with deer for food. By the end of our study, 


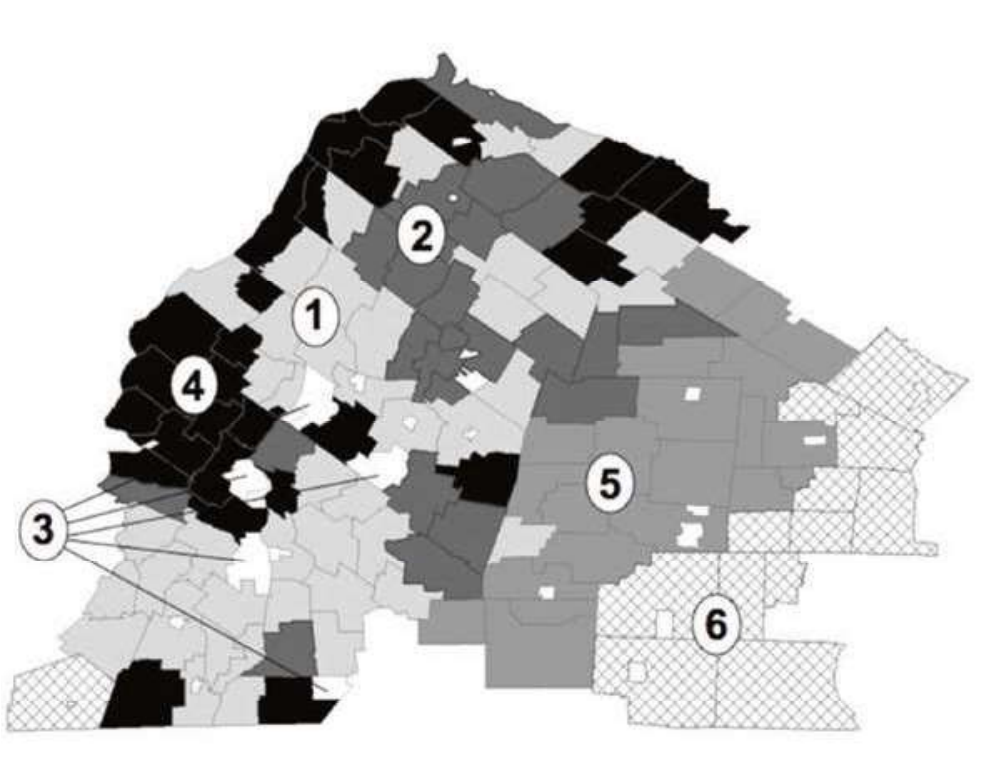

1

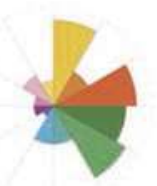

$4^{\text {COR }}$

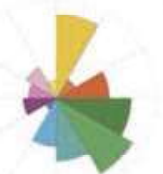

EXURBAN
2

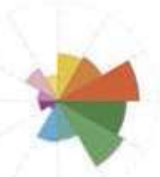

FEEDLOT AG

5

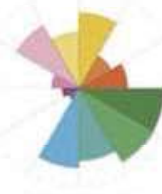

VILLAGES
3

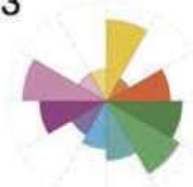

6

DEST. TOURISM

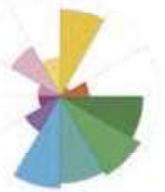

COUNTRY HOMES

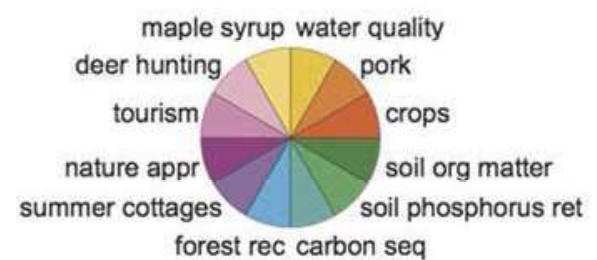

Fig. 45.3 Ecosystem service bundle types represent the average values of ecosystem services found within each cluster. Clusters in the data were also found to be clustered in space, and each ecosystem service bundle type maps onto an area of the region characterized by distinct

social-ecological dynamics, represented by the bundle names. The area depicted is the same as in Fig. 45.2. (Reproduced from RaudseppHearne et al. [8])

most animals were kept indoors or in feedlots, reducing any competition with deer for food.

In addition to these large-scale studies of ecosystem service provision that relied primarily on existing data and historical records, we also undertook finer-scale studies, in which we collected primary data on ecosystem services along a series of high resolution transects. Here, our goal was to investigate the role of forest connectivity on the provision of various services in both agricultural and forest settings. Thus, these transects were situated in agricultural and forested settings near forest patches of a variety of sizes and levels of connectivity to other forest patches. We found that landscape structure has an important role-especially forest fragment connectivity-in a number of ecosystem services.

In particular, increased forest connectivity reduced insect herbivory and aphid numbers in nearby soybean fields (Fig. 45.5a, b) [13] as well as arthropod pest control within maple tree stands (Fig. 45.5b) [13], but had little effect on aboveground carbon storage [9]. The relative locations of riparian buffers and nutrient sources to agricultural fields and watercourses also play a critical role in water quality regulation in the region [14]. We found that ES provision varies according to distance-dependent relationships within single land-use categories. For example, soybean yield increases asymptotically with distance from forest (Fig. 45.5c), whereas seed set in apple orchards declines linearly as distance to meadow increases (Fig. 45.5d) [11]. It is important to note that the nature of the relationships between landscape structure and ES provision varies widely across different ES. This is signifi- cant because it means that the consequences of a single change in landscape structure will vary substantially for different ES, significantly increasing the difficulty for managers who wish to manage for multiple services (Fig. 45.5) [4].

\section{Potential Futures}

In addition to exploring current provision across the region through existing data, and collecting data on fine resolution provision of services, we also worked with local stakeholders to develop four scenarios about the potential future of the region. These scenarios were not intended to be predictions, but to encourage thinking about the long-term future, to anticipate that surprises of some sort would likely happen, and to understand the important connections between parts of the system [14].

Such scenario planning is useful in conditions of high uncertainty, and in complex social-ecological systems such as the Montérégie [15].

The four scenarios developed by local stakeholders explore urban sprawl, the effects of changing demands for energy (and of different means to meet those demands), of economic crisis, ecological crisis (insect pests), and increased interest in green development on the set of ecosystem services provided in the region (Fig. 45.6). We explored these scenarios qualitatively and quantitatively through prototype models developed using data collected in other parts of the study. 


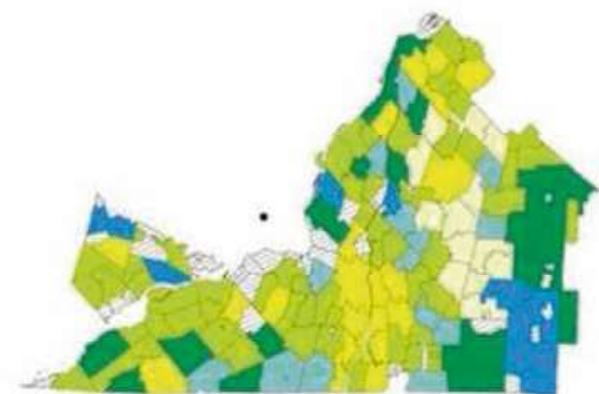

1971

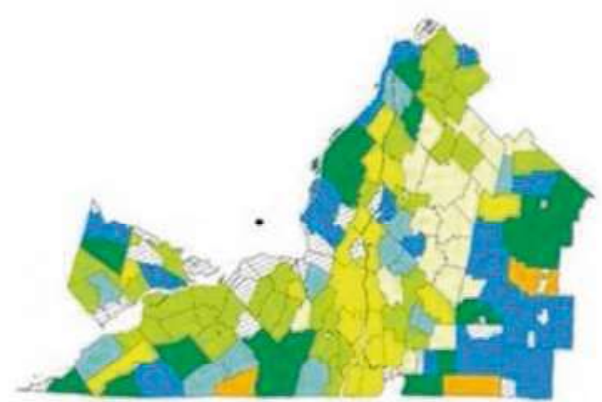

1981

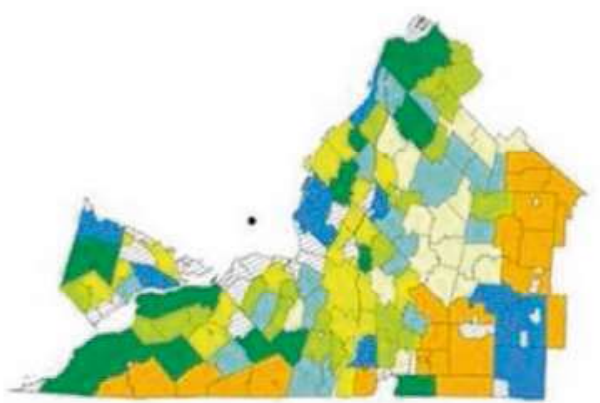

1991

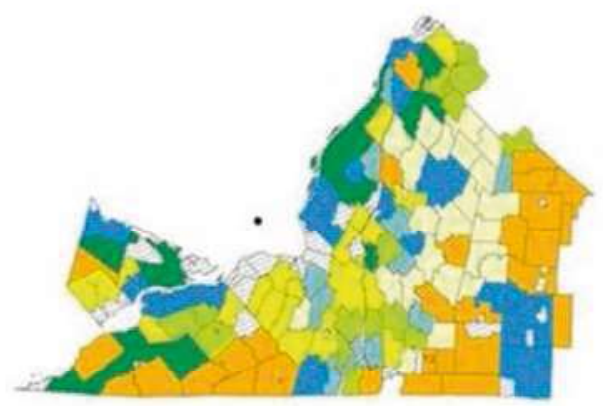

2001

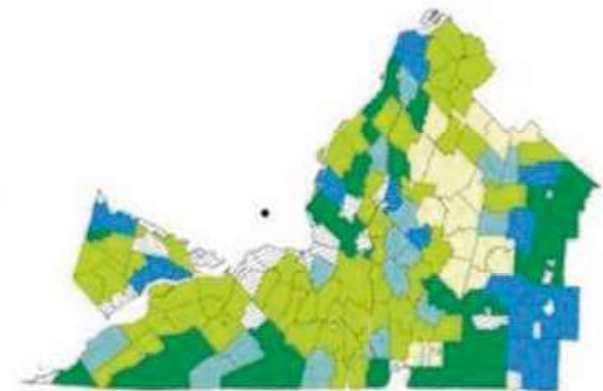

1976

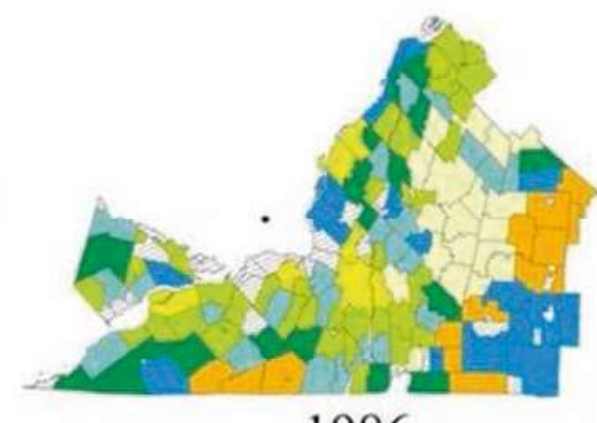

1986

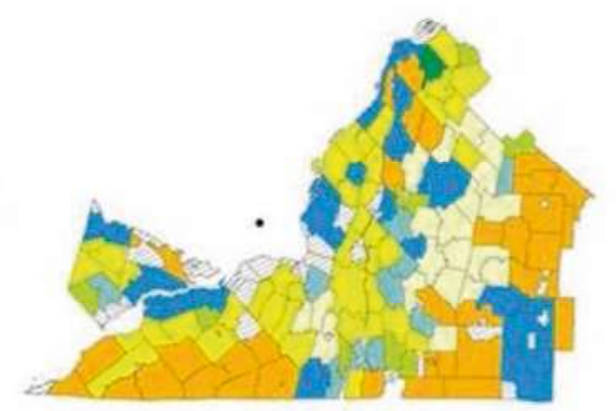

1996

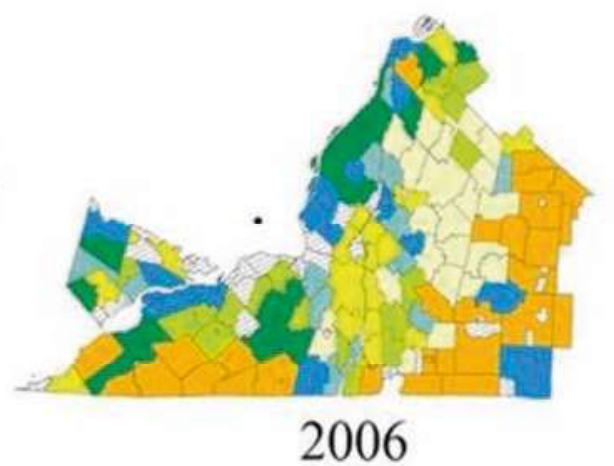

Non Available

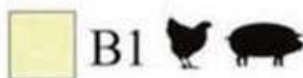

$\square$

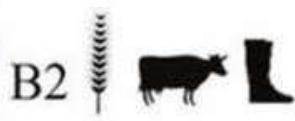

$\mathrm{B} 3$ 竎

B4

B5 X

B6 it

B7

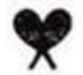

Fig. 45.4 ES bundle dynamics across space at each time step in the Montérégie. This map largely overlaps with the area depicted in the dashed line in Fig. 45.1, but extends slightly further to the west. The small dot in the middle shows the location of Montreal. Bundle 1 (B1) consists primarily of farm animals. Bundle 2 (B2) includes crops, milk production, and flood control. Bundle 3 (B3) consists primarily of crop production. Bundle 4 (B4) includes carbon storage and flood control. Bundle 5 (B5) is campsites, alongside some food production. Bundle 6 (B6) is carbon storage and game animals. Bundle 7 (B7) is recreational activities. (Reproduced from Renard et al. [12]) 
(A)
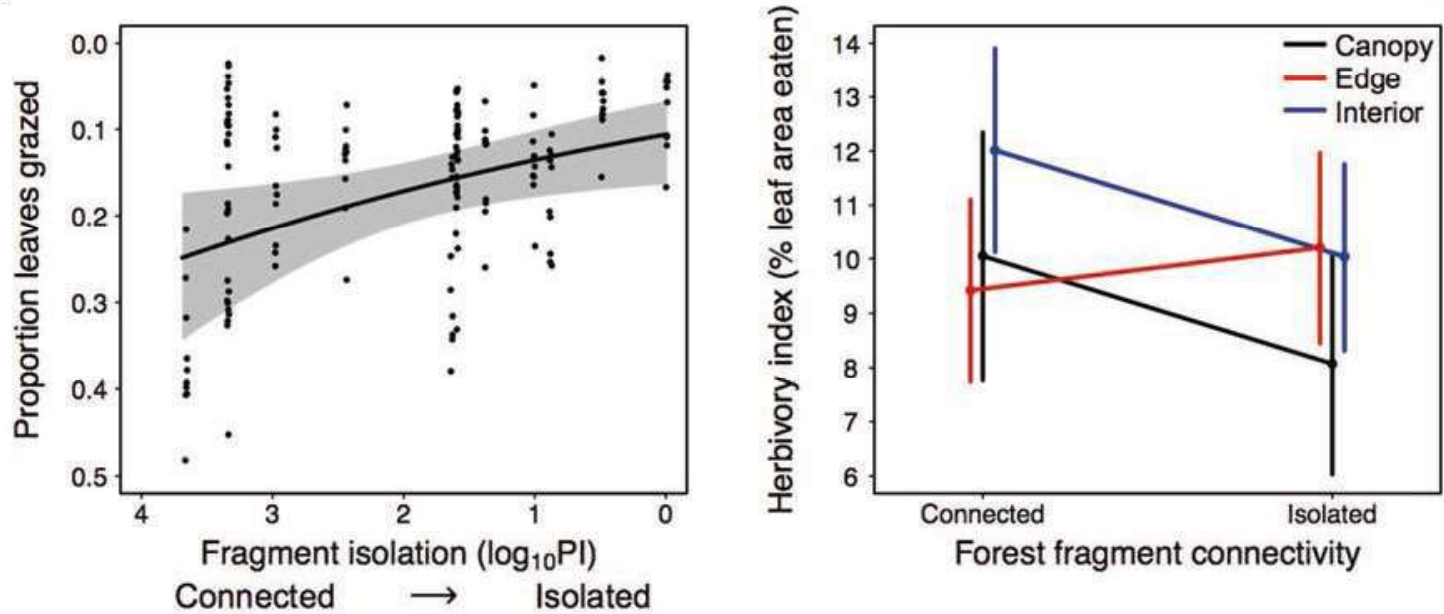

(C)

Distance decay ES relationships
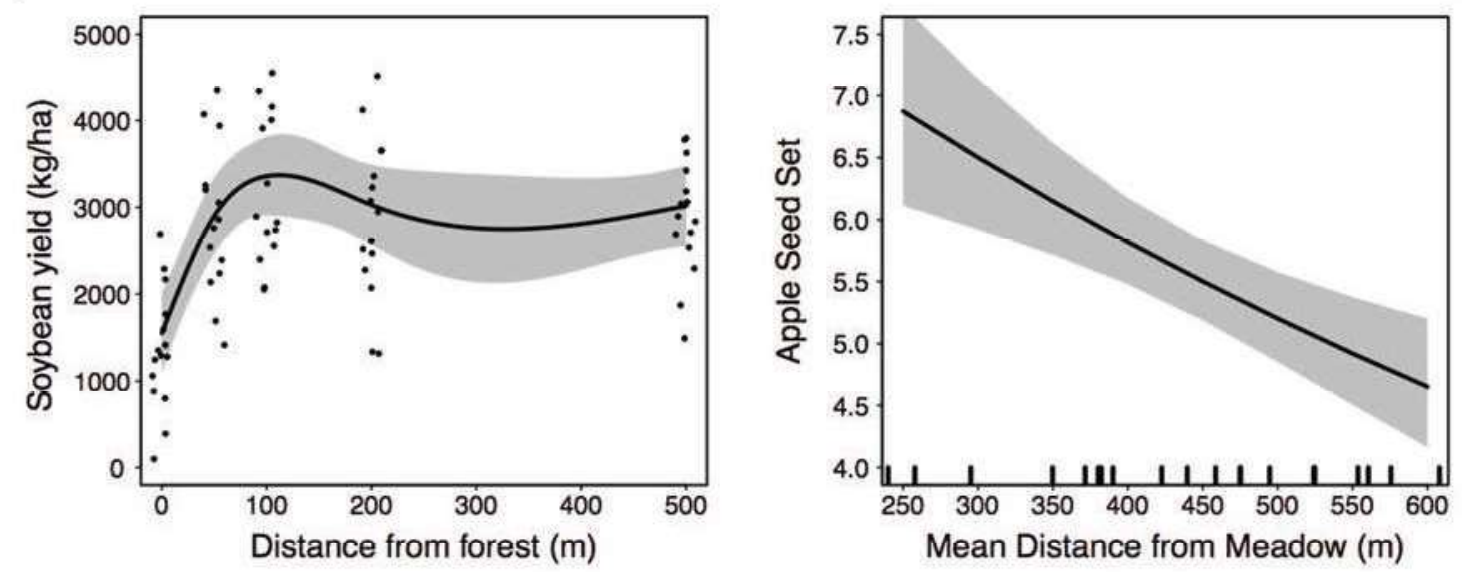

(E)

Biodiversity-ES relationships

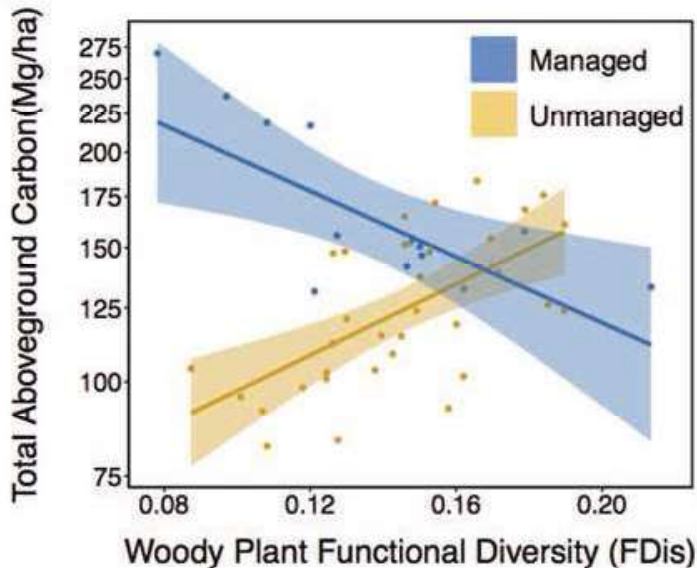

Fig. 45.5 Selected results from the Montérégie Connection project. (a) Relationships between Forest fragment isolation (PI indicates proximity index) and herbivory regulation in adjacent soybean fields; (b) Forest fragment connectivity and herbivory regulation in different types of maple tree stands; (c) Distance from forest fragment and crop yield (d) Distance from meadow and pollination services; (e) Woody plant functional diversity (functional dispersion) and carbon storage; and (f)

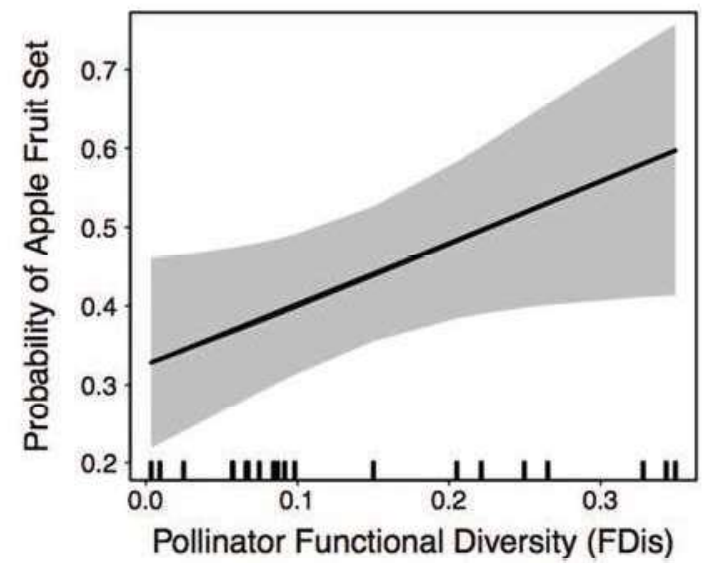

Native pollinator functional diversity (functional dispersion) and pollination services. In each, shaded areas or error bars indicate 95\% confidence intervals. In panels (a), (c), and (e), we show individual data points; in panels (d) and (f), the small lines along the $\mathrm{x}$-axis indicate sampled distances from the meadow and pollinator functional diversity, respectively. Reproduced from [11] (panels a and c); [12] (panels $\mathbf{d}$ and f) and [9] (panel e). (Reproduced from Mitchell et al. [4]) 

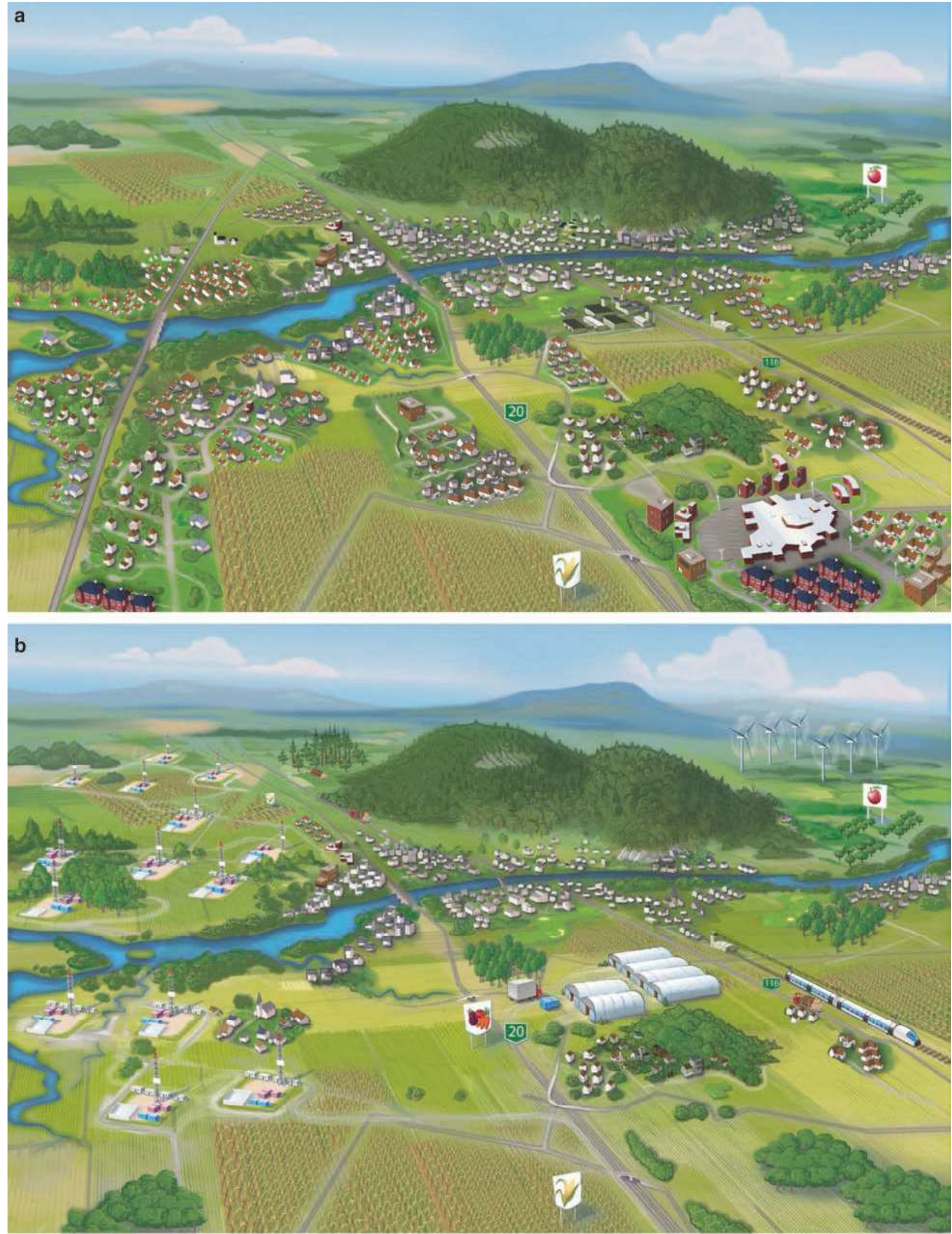

Fig. 45.6 Artist's depiction of the four VR-MRC scenarios. All illustrations are used with the permission of the artist, Denis Bainville. (a) Periurban Development scenario, in which residential growth drives loss of farmland and forests, resulting in loss of landscape connectivity and agricultural production in certain areas. (b) Demand for Energy scenario, in which shale gas development expands, resulting in farmland loss, while urban and residential development is limited. Wind power installations are also developed. (c) Systemic Crisis scenario, in which an economic crisis drives residential densification, while the Asian Long-Horned Beetle (Anoplophora glabripennis) invades, decimating the maple tree populations. Agricultural production shifts to pasture-based livestock, while marginal farmlands are converted to agro-forestry. (d) Green Development scenario, in which there is a shift toward sustainable development, with renewable energy, green corridors, protected areas, and agriculture that incorporates principles of agroforestry and agroecology 

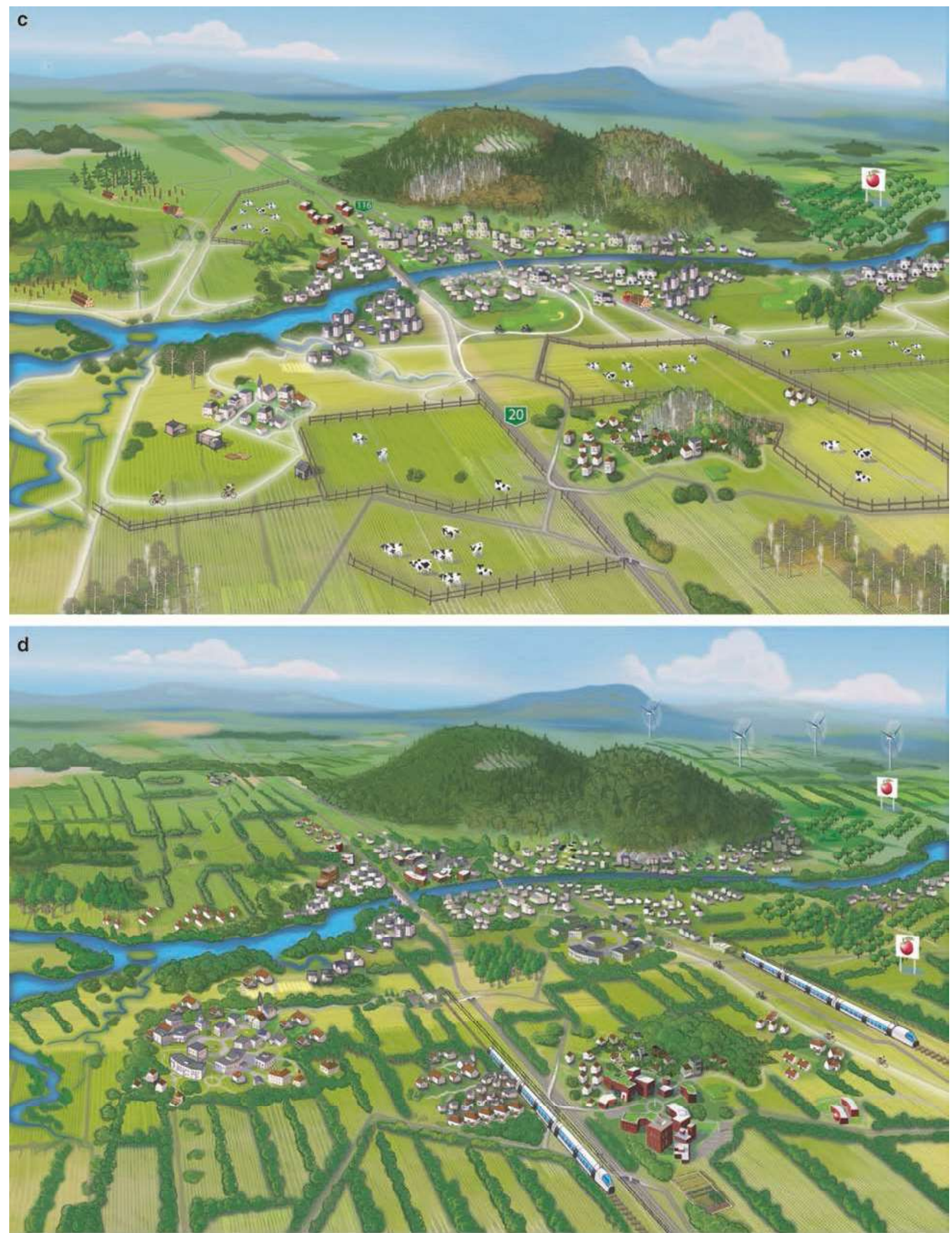

Fig. 45.6 (continued) 
Fig. 45.7 The provision of ecosystem services depends on relationships between land use/cover biodiversity, and services. We investigated these relationships in the present, past, and future through a combination of existing data, new data collection, and future scenarios development

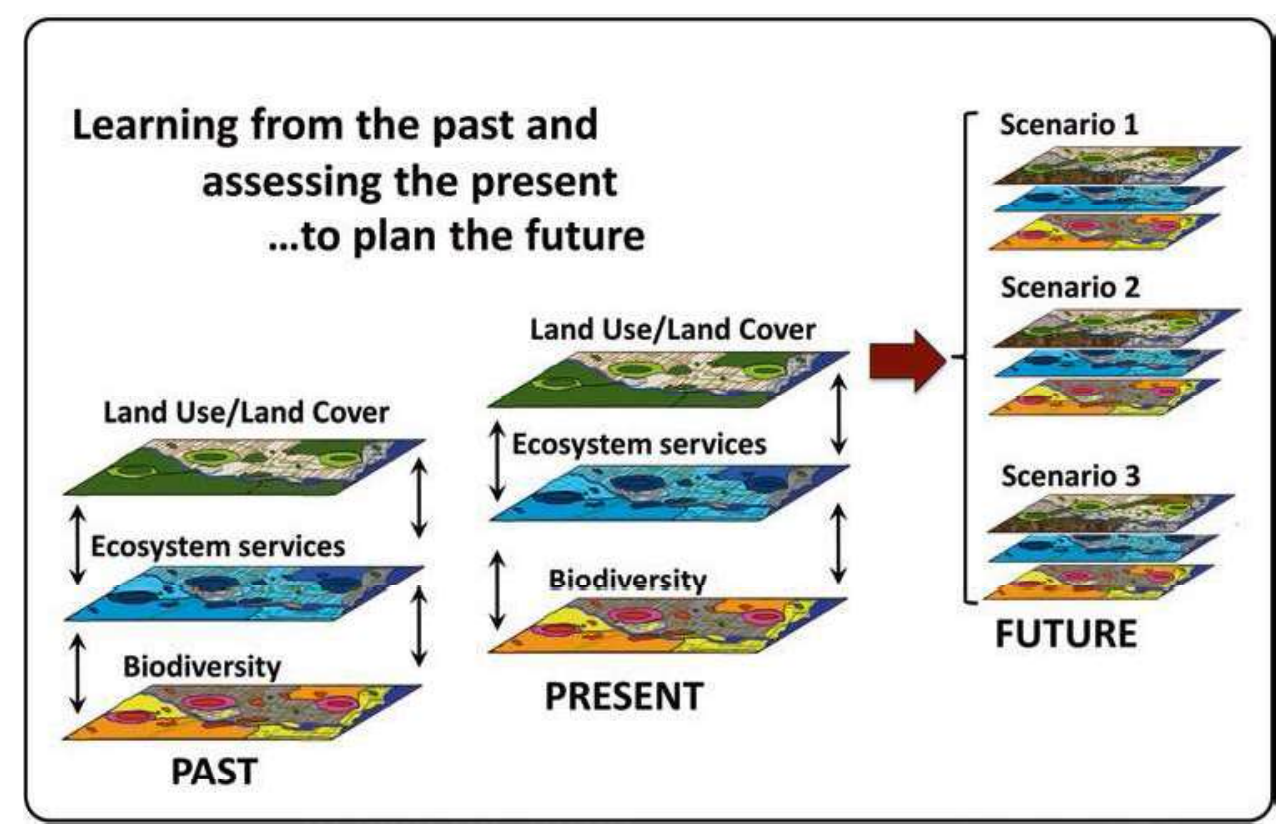

\section{Conclusions}

The project was designed to develop approaches, data, and tools that would be useful for ensuring management of healthy ecosystems in settled landscapes across Quebec and Canada. At a variety of scales, using a variety of methods, and through analysis of past, present, and future, we investigated the relationships between land use/cover, biodiversity, and ecosystem services (Fig. 45.7). We learned that the relationships between biodiversity, services, and land use/cover are highly variable among services and through time. The framework and our new understanding are a significant advance significant advance in our understanding of how human actions alter ES provision at landscape scales across social-ecological systems. Our use of scenarios, and focus on working with stakeholders to develop a true collaboration in all stages of the project, are also advances, as the ultimate value of projects like this are not just the development of new science but our ability to translate the new knowledge into tools that managers, policy makers, and other actors can comprehend and use to make better decisions.

\section{References}

1. Jobin B, Latendresse C, Grenier M, Maisonneuve C, Sebbane A Recent landscape change at the ecoregion scale in Southern Québec (Canada), 1993-2001. Environ Monit Assess. 2010;164(1):631-7.
2. Feininger T, Goodacre AK. The eight classical Montérégian hills at depth and the mechanism of intrusion. Can J Earth Sci. 1995;32:1350-64.

3. Tardif B, Lavoie G, Lachance Y. Atlas de la biodiversité du Québec-les espèces menacées ou vulnerables. Québec: Développement Durable, de l'Environnement et des Parcs; 2005. http://www.cdpnq.gouv.qc.ca/pdf/Atlas-biodiversite.pdf. Accessed 31 Oct 2017

4. Mitchell MGE, Bennett EM, Gonzalez A, Lechowicz M, Rhemtulla J, Cardille JA, et al. Montérégie connection: linking landscapes, biodiversity, and ecosystem services to improve decision making. Ecol Soc. 2015;20(4):15.

5. Bélanger L, Grenier M. Agriculture intensification and forest fragmentation in the St. Lawrence valley, Québec, Canada. Landsc Ecol. 2002; 17:495-507.

6. Dupras J, Alam M. Urban sprawl and ecosystem services: a half century perspective in the Montreal area (Quebec, Canada). J Environ Pol Plan. 2014;17(2):180-200

7. Carpenter SR, Mooney HA, Agard J, Capistrano D, DeFries RS, Diaz S, et al. Science for managing ecosystem services: beyond the Millennium Ecosystem Assessment. Proc Natl Acad Sci U S A. 2009;106(5):1305-12.

8. Raudsepp-Hearne C, Peterson GD, Bennett EM. Ecosystem service bundles for analyzing tradeoffs in diverse landscapes. Proc Natl Acad Sci U S A. 2010;107(11):5242-7.

9. Ziter C, Gonzalez A, Bennett EM. Functional diversity and management mediate carbon storage in small forest fragments. Ecosphere. 2013;4(7):85

10. Mitchell MGE, Bennett EM, Gonzalez A. Agricultural landscape structure affects arthropod diversity and arthropodderived ecosystem services. Agric Ecosyst Environ. 2014;192: 144-51.

11. Martins KT, Gonzalez A, Lechowicz MJ. Pollination services are mediated by bee functional diversity and landscape context. Agric Ecosyst Environ. 2014;200:12-20. 
12. Renard D, Rhemtulla JM, Bennett EM. Historical dynamics in ecosystem service bundles. Proc Natl Acad Sci U S A. 2015;112(43):13411-6.

13. Maguire DY, James PMA, Buddle C, Bennett EM. Landscape connectivity and insect herbivory: a framework for understanding tradeoffs among ecosystem services. Glob Ecol Conserv. 2015;4:73-84.
14. Peterson GD, Cumming GS, Carpenter SR. Scenario planning: a tool for conservation in an uncertain world. Conserv Biol. 2003;17(2):358-66.

15. Carpenter SR, Bennett EM, Peterson GD. Scenarios for ecosystem services: an overview. Ecol Soc. 2006;11(1):29.
E. M. Bennett $(\bowtie) \cdot$ J. Cardille $\cdot$ S. Delmotte $\cdot$ K. Liss $\cdot$ D. Maguire C. Raudsepp-Hearne $\cdot$ L. Taliana

McGill School of Environment, McGill University,

Montreal, QC, Canada

Department of Natural Resource Sciences, McGill University, Montreal, QC, Canada

e-mail: elena.bennett@mcgill.ca; jeffrey.cardille@mcgill.ca;

Sylvestre.Delmotte@mcgill.ca; katie.liss@mcgill.ca; dorothy. maguire@mcgill.ca; ciara.raudsepp-Hearne@ mcgill.ca; lucie. taliana@mcgill.ca

\section{Albert}

Mediterranean Institute of Biodiversity and Marine and Land Ecology (IMBE), Aix-Marseille University, UMR CNRS 7263/ IRD 237, Aix-en-Provence cedex 04, France

e-mail: cecile.albert@imbe.fr

A. Ball

Queen's Sustainability Office, Queen's University,

Kingston, ON, Canada

e-mail: balla@queensu.ca

\section{K. Dancose}

University of Sherbrooke, Sherbrooke, QC, Canada

e-mail: karine.dancose@USherbrooke.ca

A. Gonzalez $\cdot$ K. Teixeira-Martins

Department of Biology, Quebec Centre for Biodiversity Science, Montreal, QC, Canada

e-mail: andrew.gonzalez@mcgill.ca; kyle.teixeira-martins@ mcgill.ca

H. Hui-Huang

McGill School of Environment, McGill University, Montreal, QC, Canada

Department of Bioresource Engineering, McGill University,

Montreal, QC, Canada

e-mail: hsin-hui.huang@mail.mcgill.ca
M. Lechowicz

Department of Biology, McGill University, Montreal, QC, Canada e-mail: martin.lechowicz@mcgill.ca

R. Kipp

Department of Atmospheric and Oceanic Sciences, McGill

University, Montreal, QC, Canada

e-mail: rebekah.kipp@mail.mcgill.ca

\section{S. Mahajan}

World Wildlife Fund, Washington, DC, USA

e-mail: shauna.mahajan@wwfus.org

\section{Mitchell}

Institute for Resources, Environment, and Sustainability,

The University of British Columbia, Vancouver, BC, Canada e-mail: matthew.mitchell@ubc.ca

\section{Renard}

Bren School of Environmental Science and Management,

Earth Research Institute, University of California, Santa Barbara, Santa Barbara, CA, USA

J. Rhemtulla

Forest and Conservation Sciences, Forest Sciences Centre,

Vancouver, BC, Canada

e-mail: jeanine.rhemtulla@ubc.ca

M. Terrado

Barcelona Supercomputing Center, Earth Sciences-Earth System Services Group, Barcelona, Spain

e-mail: marta.terrado@bsc.es

C. Ziter

Department of Biology, Concordia University, Montreal, Canada e-mail: ziter@wisc.edu 